\title{
GENETIC VARIATION AND GENETIC STRUCTURE OF TWO CLOSELY RELATED DIPTEROCARP SPECIES, DRYOBALANOPS AROMATICA C.F.GAERTN. AND D. BECCARII DYER
}

\author{
Ko Harada', Fifi Gus Dwiyanti², Iskandar Zulkarnaen Siregar ${ }^{3}$, Atok Subiakto ${ }^{4}$, \\ Lucy Chong ${ }^{5}$, Bibian Diway ${ }^{6}$,Ying-Fah Lee ${ }^{7}$, Ikuo Ninomiya ${ }^{8}$ \& Koichi Kamiya ${ }^{9}$
}

\begin{abstract}
Large-scale genetic structure revealed in tree populations in SE Asia, as well as in many temperate forests, has been shaped by climatic fluctuation in the late Pleistocene, most importantly by that in the last glacial period. In a comparative study of the phylogeographic patterns of two closely related dipterocarp species, Dryobalanops aromatica C.F.Gaertn. and D. beccarii Dyer, we investigated how changes in land area associated with changes in climate affected large-scale genetic structure. We examined the genetic variation of $D$. aromatica, collected from nine populations throughout the Sundaic region, and of $D$. beccarii, collected from 16 populations mainly in Borneo, using seven polymorphic microsatellite markers. The two species were clearly distinguishable in the STRUCTURE analysis, although hybridisation probably occurred in sympatric populations and also in several other populations. The $D$. aromatica populations were divided into two main groups by the STRUCTURE analysis: Malay-Sumatra and Borneo. Mixing of the Sumatra and Borneo clusters occurred on the Malay Peninsula, supporting the hypothesis that tropical rainforests expanded over a dried Sunda Shelf during the last glacial period. The two main genetic clusters might have been formed by repeated cycles of fluctuation in land area. The $D$. beccarii populations in Borneo were divided into four geographically distinct groups: western Sarawak, central inland Sarawak, central coastal Sarawak and Sabah. The population on the Malay Peninsula (Gunung Panti) was an admixture of the four Bornean clusters. This suggests that this population is a relic of the recent range expansion of $D$. beccarii during the last glacial period.
\end{abstract}

\footnotetext{
1. Ko Harada PhD is a Professor Emeritus in the Faculty of Agriculture, Ehime University.

Address: 3-5-7 Tarumi, Matsuyama, Ehime 790-8566, Japan.

Email: kharada@agr.ehime-u.ac.jp

2. Fifi Gus Dwiyanti PhD is a Researcher in the Faculty of Forestry, Bogor Agricultural University, Indonesia.

Address: Darmaga Campus, PO Box 168, Bogor 16680, Indonesia.

3. Iskandar Zulkarnaen Siregar PhD is a Professor in the Faculty of Forestry, Bogor Agricultural University, Indonesia.

Address: as above.

4. Atok Subiakto MS is a Senior Researcher in the Forest and Nature Conservation Research and Development Center,

Bogor, Indonesia.

Address: Jl Gunung Batu No. 5, Bogor 16001, Indonesia.

5. Lucy Chong BSc is a Senior Researcher at the Botanical Research Centre, Sarawak, Malaysia.

Address: Km 20 Jalan Puncak Borneo, Semenggoh Kuching, Sarawak, 93250, Malaysia.

6. Bibian Diway BSc is a Senior Researcher at the Botanical Research Centre, Sarawak, Malaysia.

Address: Km 20 Jalan Puncak Borneo, Semenggoh Kuching, Sarawak, 93250, Malaysia.

7. Ying Fah Lee PhD is a Director of the Forest Research Centre, Forest Department Sabah.

Address: Km 23, Labuk Road, Sepilok, PO Box 1407, Sandakan, Sabah, 90715, Malaysia

8. Ikuo Ninomiya $\mathrm{PhD}$ is a Professor in the Graduate School of Agriculture, Ehime University.

Address: 3-5-7 Tarumi, Matsuyama, Ehime 790-8566, Japan.

9. Koichi Kamiya PhD is an Associate Professor in the Graduate School of Agriculture, Ehime University.

Address: 3-5-7 Tarumi, Matsuyama, Ehime 790-8566, Japan.
} 


\section{INTRODUCTION}

The Sundaic region is a part of western Malesia comprising Peninsular Malaysia, Sumatra, Borneo, Java and their surrounding islands. Approximately 15,000 plant species are endemic to the Sundaic region - about $5 \%$ of the global total of plant species (Myers et al., 2000). This region with its immense and unique biodiversity in parallel with ongoing rapid degradation of forests has been identified as one of the hottest hotspots in the world (Myers et al., 2000; Conservation International, 2010). Since the beginning of the 20th century, especially in the second half, deforestation has been accelerating as a result of increasing human activities such as intensive logging, conversion of forest areas to large-scale plantations and expansion of agricultural land (e.g. FAO, 2010; Langner et al., 2007; Hansen et al., 2010). The overall annual deforestation level in this region remained above 1\% from 2000 to 2010 (Miettinen et al., 2011). The importance of conservation of rainforests in tropical Asia coupled with sustainable development of rural communities has been broadly discussed (Sodhi et al., 2004; Ghazoul \& Sheil, 2010; Corlett, 2014).

In the last two decades, various kinds of genetic markers have been developed and adapted for studying plant genetic diversity and population genetic structure in tropical forests, as well as in temperate forests. Genetic diversity and genetic structure in plant species are both influenced by many factors, but at different levels. Some of them are intrinsic to the life history of a species (breeding system, modes of seed and pollen dispersal, life form, gregariousness), whereas others are historical processes (large-scale distribution range shifts) associated with changes in climate, especially during the ice ages and human impact (habitat fragmentation by cutting, density change as a result of selective logging) (Hamrick et al., 1992; Heuertz et al., 2004). Fine-scale spatial genetic structure can often be generated in the first case, as has been reported in tropical rainforest trees (Takeuchi et al., 2004; Harata et al., 2011; Kettle et al., 2011; Ismail et al., 2012; Kettle et al., 2012; de Morais et al., 2015). However, climatic fluctuations during the Quaternary strongly affected their large-scale genetic structure (Comes \& Kadereit, 1998; Hewitt, 2000; Ishiyama et al., 2008; Iwanaga et al., 2012; Kamiya et al., 2012; Ohtani et al., 2013). Drastic environmental changes have been caused by human activity; however, the effect on the genetic diversity and structure of tree populations may not occur concurrently, because of the long life cycle of trees (Finger et al., 2012). However, some change in breeding systems, caused by selective logging and the resulting inbreeding depression, have already been reported in Asian tropical rainforest trees (Obayashi et al., 2002; Naito et al., 2005; Fukue et al., 2007; Naito et al., 2008; Ismail et al., 2012).

The lowland evergreen forests of the SE Asian tropics are characterised by an abundance of dipterocarp trees (Dipterocarpaceae). Over 400 species in 11 genera are recognised in the area centring on the Sundaic region (Ashton, 1982). Dryobalanops C.F.Gaertn. is one of the smallest genera of Dipterocarpaceae, and contains only seven known species: D. aromatica C.F.Gaertn., D. oblongifolia Dyer, D. beccarii Dyer, D. 
fusca Slooten, D. keithii Symington, D. lanceolata Burck and D. rappa Becc. All seven species occur in Borneo, and the genus is centred in the north-western part of this island, where four of the species (D. fusca, D. keithii, D. lanceolata and D. rappa) are endemic (Ashton, 1982). D. aromatica, D. beccarii, D. lanceolata and D. oblongifolia, which are locally known as kapur (Ashton, 1982; Symington, 2004), grow tall (more than $70 \mathrm{~m}$ ) and have been an important source of timber. They are essentially outbreeding, and are pollinated by insects. The seeds are dispersed by gravity or by gyration, as they have winged fruits (Appanah \& Turnbull, 1998). They used to be common (Newman et al., 1998; Chua et al., 2010), but their habitat is currently greatly reduced, and four of the seven species are listed as threatened in the 2017 IUCN Red List: D. fusca and D. keithii, both Critically Endangered, and D. beccarii and D. lanceolata, both Endangered (IUCN, 2017).

In this study, we examined the genetic structure of $D$. aromatica, which occurs throughout Peninsular Malaysia, Sumatra and Borneo. We also examined D. beccarii, which has a broad distribution in Borneo from latitude $2^{\circ} \mathrm{N}$ northwards, and grows especially on inland slopes, but whose distribution is limited outside Borneo. Only one isolated population is known outside of Borneo, in Panti Forest Reserve in Johor, Malaysia (Ashton, 1982). These two species are genetically closely related (Dwiyanti et $a l ., 2015)$. The two species are recognised as morphologically and ecologically distinct, but identification is often difficult in the field, especially in the absence of flowers or fruits (Symington, 2004; Chua et al., 2010). We examined the genetic variation and genetic structure of these species using microsatellite markers. Microsatellites are essentially neutral, and changes in allele frequency are based on purely stochastic processes (Li, 1997). These markers therefore have great potential to detect genetic structure that is shaped by stochastic processes related to historical changes in climate. Comparative analysis of genetic diversity and structure will provide deeper insight into the phylogeographic orientation of the present distribution of the species. This can also be useful for zoning potential natural vegetation projected on the scattered and fragmented habitats (Tüxen, 1956). This will provide spatial extent and configuration of forests for determining conservation and management units, to define the first approximation of areas to which the species is locally adapted (Manel et al., 2003).

\section{MATERIALS AND METHODS}

\section{Plant materials}

Samples of leaf material were collected from nine populations of D. aromatica and 16 populations of $D$. beccarii (Table 1, Fig. 1). Samples were collected from across the current distribution ranges of these species in Peninsular Malaysia, in Sumatra and in Borneo. In total, 219 D. aromatica individuals and 235 D. beccarii individuals were sampled. Plant materials were dried in the field using silica gel and kept at $-30^{\circ} \mathrm{C}$ until they were processed for DNA extraction. In the laboratory, samples were ground to a 


\begin{tabular}{|c|c|c|c|c|}
\hline \multicolumn{5}{|c|}{ D. aromatica } \\
\hline Code & Population & Sample size & Location & Coordinates \\
\hline A1 & Singkil & 23 & Sumatra & $2.3589 \mathrm{~N}, 97.8722 \mathrm{E}$ \\
\hline A 2 & Barus & 6 & Sumatra & $2.0692 \mathrm{~N}, 98.3578 \mathrm{E}$ \\
\hline A3 & Mursala & 51 & Sumatra & $1.6731 \mathrm{~N}, 98.4967 \mathrm{E}$ \\
\hline A4 & Kancing & 13 & Peninsular Malaysia & $3.3042 \mathrm{~N}, 101.6114 \mathrm{E}$ \\
\hline A5 & Gunung Panti & 23 & Peninsular Malaysia & $1.8278 \mathrm{~N}, 103.8669 \mathrm{E}$ \\
\hline A6 & Lingga & 20 & Lingga Isl. & $1.5086 \mathrm{~N}, 104.6372 \mathrm{E}$ \\
\hline A7 & Similajau & 32 & Sarawak & $3.4503 \mathrm{~N}, 113.2808 \mathrm{E}$ \\
\hline A8 & Lambir & 28 & Sarawak & $4.2131 \mathrm{~N}, 114.03 \mathrm{E}$ \\
\hline A9 & Limbang & 27 & Sarawak & $4.7544 \mathrm{~N}, 114.9908 \mathrm{E}$ \\
\hline \multicolumn{5}{|c|}{ D. beccarii } \\
\hline Code & Population & Sample size & Location & Coordinates \\
\hline B1 & Gunung Panti & 3 & Peninsular Malaysia & $1.8278 \mathrm{~N}, 103.8669 \mathrm{E}$ \\
\hline B2 & Gunung Gading & 28 & Sarawak & $1.6902 \mathrm{~N}, 109.8458 \mathrm{E}$ \\
\hline B3 & Kubah N.P. & 15 & Sarawak & $1.6131 \mathrm{~N}, 110.19694 \mathrm{E}$ \\
\hline B4 & Kuching & 7 & Sarawak & $1.6781 \mathrm{~N}, 110.4147 \mathrm{E}$ \\
\hline B5 & Bako N.P. & 28 & Sarawak & $1.7253 \mathrm{~N}, 110.4664 \mathrm{E}$ \\
\hline B6 & Bukit Lingang & 6 & Sarawak & $1.5308 \mathrm{~N}, 111.7794 \mathrm{E}$ \\
\hline B7 & Lubok Antu & 5 & Sarawak & $1.3006 \mathrm{~N}, 111.8467 \mathrm{E}$ \\
\hline B8 & Batang Ai N.P. & 35 & Sarawak & $1.2219 \mathrm{~N}, 111.9464 \mathrm{E}$ \\
\hline B9 & Bukit Tangii & 32 & Sarawak & $2.6080 \mathrm{~N}, 111.95 \mathrm{E}$ \\
\hline B10 & Mukah & 15 & Sarawak & $2.4678 \mathrm{~N}, 112.6169 \mathrm{E}$ \\
\hline B11 & Nyabau & 10 & Sarawak & $3.23361 \mathrm{~N}, 113.1 \mathrm{E}$ \\
\hline B12 & Similajau N.P. & 13 & Sarawak & $3.4503 \mathrm{~N}, 113.2808 \mathrm{E}$ \\
\hline B13 & Bukit Tiban & 8 & Sarawak & $3.4581 \mathrm{~N}, 113.4978 \mathrm{E}$ \\
\hline B14 & Sungai Asap & 10 & Sarawak & $3.0378 \mathrm{~N}, 113.93389 \mathrm{E}$ \\
\hline B15 & Bakun Dam & 6 & Sarawak & $2.7564 \mathrm{~N}, 114.0631 \mathrm{E}$ \\
\hline B16 & Deramakot & 14 & Sabah & $5.3533 \mathrm{~N}, 117.4086 \mathrm{E}$ \\
\hline
\end{tabular}

Populations are in the order that they occur from west to east along each line of latitude. N.P. National Park.

Table 1 Sampling locations of D. aromatica and D. beccarii. 


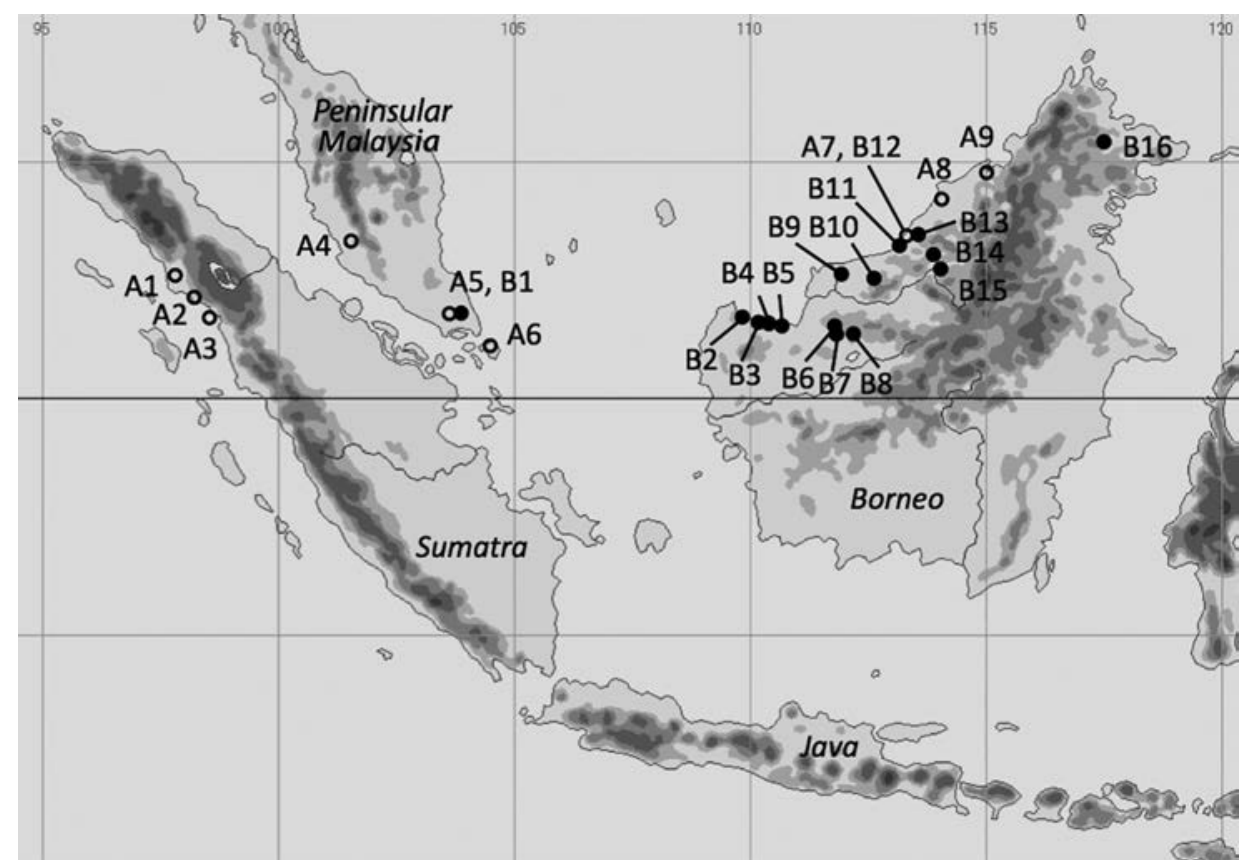

Fig. 1 Map of the sampling locations of nine populations of $D$. aromatica (open circles) and 16 populations of $D$. beccarii (closed circles).

fine powder using a TissueLyser II (QIAGEN Japan, Tokyo). Total genomic DNA was extracted using the modified CTAB method (Doyle \& Doyle, 1990).

\section{Microsatellite genotyping}

The genetic variation of eight microsatellite loci was examined for both species. Of these, seven (Dra187, Dra428, Dra426, Dra519, Dra266, Dra471 and Dra569) had been developed for D. aromatica (Nanami et al., 2007) and one (Sle384) for Shorea leprosula (Lee et al., 2004). The forward primer for each marker was labelled with 6-FAM, VIC, NED or PET phosphoramidite (Applied Biosystems Japan, Tokyo). A Type-it Microsatellite PCR kit (QIAGEN Japan, Tokyo) was used to amplify the microsatellite loci. Multiplex PCR amplification was performed in a volume of $5 \mu \mathrm{l}$, containing 1×Type-it Multiplex PCR Master mix, $0.2 \mu \mathrm{M}$ of forward and reverse primers, and approximately $40 \mathrm{ng}$ of genomic DNA. A 2720 Thermal Cycler (Applied Biosystems Japan) was used under the following conditions: initial denaturation at $95^{\circ} \mathrm{C}$ for $5 \mathrm{~min}$, then 31 cycles of denaturation at $95^{\circ} \mathrm{C}$ for $30 \mathrm{~s}$, annealing for $90 \mathrm{~s}$ and extension at $72^{\circ} \mathrm{C}$ for $30 \mathrm{~s}$, followed by a final incubation at $60^{\circ} \mathrm{C}$ for $30 \mathrm{~min}$. The annealing temperature was $52-57^{\circ} \mathrm{C}$. Fragment sizes were determined using an ABI PRISM 310 Genetic Analyzer and visualised using the GeneMapper 3.0 software (Applied Biosystems Japan). 


\section{Microsatellite data analysis}

The existence of null alleles was examined using Micro-checker (Oosterhout et al., 2004). The linkage disequilibrium between pairs of loci was examined with FSTAT 2.9.3.2 (Goudet, 2001), based on 100 permutations for each test. Basic statistics, including the mean number of alleles per locus $\left(N_{\mathrm{a}}\right)$, effective number of alleles $\left(N_{\mathrm{e}}\right)$ for each population of each species, observed heterozygosity $\left(H_{o}\right)$, expected heterozygosity $\left(H_{\mathrm{e}}\right)$ and Wright's inbreeding coefficient $(F)$, were calculated using GenAlEx version 6.41 (Peakall \& Smouse, 2006). Allele richness $\left(A_{\mathrm{r}}\right)$ was calculated using FSTAT 2.9.3.2 (Goudet, 2001). The F-statistics $F_{\mathrm{IS}}, F_{\mathrm{ST}}$ and $F_{\mathrm{IT}}$ (Weir \& Cockerham, 1984) were calculated to determine the level of population differentiation, using FSTAT. Standard errors and confidence intervals were estimated using the jack knife and bootstrap methods, respectively, implemented in FSTAT. Selective neutrality for the loci was examined by means of an $F_{\mathrm{ST}}$ outlier method (Beaumont \& Nichols, 1996) using the LOSITAN software (Antao et al., 2008). We performed 50,000 simulations with a stepwise mutation model. Candidate loci which may have been under positive selection or balancing selection were identified as outliers based on $99 \%$ confidence intervals. Because the sample size of some populations was very small, we used populations with a sample size of more than ten for all the above estimates.

A Bayesian model-based clustering analysis implemented in STRUCTURE version 2.3.4 (Pritchard et al., 2000) was used to estimate the number of genetically homogeneous groups of individuals or clusters $(K)$ and determine the genetic structure of the sampled populations. A Markov chain Monte Carlo (MCMC) simulation of $4 \times$ $10^{5}$ steps, preceded by a burn-in of $2 \times 10^{5}$ steps, was performed using admixture and allele size-correlated models, with the LocPrior option. The program was run with ten replications each for the range $K=1-10$ for the combined $D$. aromatica and $D$. beccarii dataset, and also for the two datasets separately. In order to evaluate the likelihood of $K$, we uploaded the STRUCTURE-generated results to the online program STRUCTURE HARVESTER (Earl \& von Holdt, 2012) and obtained plots of the mean likelihood value $(\operatorname{Ln} \operatorname{Pr} X / K)$ and $\Delta K$ for successive values of $K$. We then determined the optimum values of $K$, following Evanno et al. (2005). For certain values of $K$ the replicated results were aligned using CLUMPP version 1.1.2 (Jakobsson \& Rosenberg, 2007) and visualised using DISTRUCT (Rosenberg, 2004). The existence of population bottlenecks was assessed using BOTTLENECK version 1.2.02 (Cornuet \& Luikart, 1998), by testing for positive or negative deviations in observed heterozygosity from the expected value under mutation-drift balance. We used a two-phase model (TPM) and tested it using the Wilcoxon signed-rank test because of the small number of loci (Luikart et al., 1998). Geographic barriers to genetic exchange were visualised using the software BARRIER version 2.2 (Manni et al., 2004). The software implements Monmonier's maximum difference algorithms and identifies genetic barriers on a geographic map, based on the genetic distance matrix and coordination data (Monmonier, 1973). The number of barriers is set arbitrarily. The reliability of 
the barriers was evaluated by bootstrapping, based on 100 permutations of the dataset generated by the Microsatellite Analyzer (MSA) software (Dieringer \& Schlötterer, 2003). The distance matrix was constructed based on Nei's (1978) pairwise standardised genetic distance.

\section{RESULTS}

\section{Null alleles and linkage disequilibrium}

The existence of null alleles was examined for the eight microsatellite loci. Null alleles were detected in 14 out of 25 populations (three in D. aromatica and 11 in D. beccarii) at the locus Dra471. In addition, they were detected in four, five, three, one and four populations at the loci Dra187, Dra428, Dra519, Dra266 and Sle384, respectively. We excluded Dra471 from the following analysis. Linkage disequilibrium was examined separately for $D$. aromatica and $D$. beccarii. Seven out of 183 tests on $D$. aromatica and two out of 169 tests on D. beccarii were significant at the 5\% level after applying the Bonferroni correction. Furthermore, none of the remaining seven loci (after the exclusion of Dra471) were identified as outliers by LOSITAN. We concluded that these loci were neutral and sufficiently independent for the application of Bayesian and other methods to the population demography analysis.

\section{Genetic variation}

A total of 132 alleles were detected at the seven loci across the combined $D$. beccarii and D. aromatica dataset. The estimated population genetic parameters are listed in Table 2. The 95\% confidence interval (CI) for $H_{\mathrm{e}}$ was $0.603-0.611$ for $D$. aromatica and $0.321-$ 0.487 for $D$. beccarii. The $95 \%$ CI for $A_{\mathrm{r}}$ was 5.32-8.91 for $D$. aromatica and 3.30-6.71 for $D$. beccarii. $H_{\mathrm{e}}$ was significantly larger in $D$. aromatica than in $D$. beccarii. $A_{\mathrm{r}}$ was larger in $D$. aromatica than $D$. beccarii, but not significantly. The coefficient of genetic differentiation, $F_{\mathrm{ST}}$, was significantly greater than zero in both species (at the $99 \% \mathrm{CI}$ level). It was larger in D. beccarii than in D. aromatica (at the $95 \%$ CI level). The overall inbreeding coefficient, $F_{\text {IS }}$, was not significantly different from zero at the $99 \%$ CI level in either species (Table 3). A significant heterozygosity deficit was detected by the BOTTLENECK analysis in the A8 (Lambir) and A9 (Limbang) populations of $D$. aromatica, and in the B5 (Bako) and B9 (Bukit Tangii) populations of D. beccarii. This suggests a recent population expansion in these populations. None of the populations showed any signs of a recent bottleneck.

\section{Genetic structure}

The STRUCTURE analysis was performed first on the combined $D$. aromatica and $D$. beccarii dataset. The most likely number of genetic clusters was $K=2$, since a single 


\begin{tabular}{|c|c|c|c|c|c|c|c|c|c|c|c|}
\hline \multicolumn{9}{|c|}{ D. aromatica } & \multicolumn{3}{|c|}{ Wilcoxon test ${ }^{\ddagger}$} \\
\hline Population & & $N$ & $N_{\mathrm{a}}$ & $N_{e}$ & $A_{\mathrm{r}}$ & $\mathrm{H}_{0}$ & $\mathrm{H}_{\mathrm{e}}$ & $F$ & a & b & c \\
\hline \multirow[t]{2}{*}{ Singkil } & Mean & 23 & 7.00 & 3.39 & 5.28 & 0.646 & 0.657 & 0.026 & 0.718 & 0.531 & 1.000 \\
\hline & $\mathrm{SE}^{\dagger}$ & & 1.36 & 0.56 & 0.77 & 0.085 & 0.052 & 0.087 & & & \\
\hline \multirow[t]{2}{*}{ Mursala } & Mean & 51 & 7.71 & 3.71 & 5.24 & 0.538 & 0.635 & 0.192 & 0.718 & 0.344 & 0.688 \\
\hline & SE & & 1.48 & 0.70 & 0.79 & 0.104 & 0.099 & 0.090 & & & \\
\hline \multirow[t]{2}{*}{ Kancing } & Mean & 23 & 4.57 & 2.82 & 4.01 & 0.609 & 0.585 & -0.083 & 0.406 & 0.656 & 0.812 \\
\hline & SE & & 0.69 & 0.52 & 0.54 & 0.034 & 0.057 & 0.096 & & & \\
\hline \multirow[t]{2}{*}{ Gunung Panti } & Mean & 20 & 5.71 & 3.43 & 4.79 & 0.500 & 0.655 & 0.204 & 0.945 & 0.148 & 0.297 \\
\hline & SE & & 0.84 & 0.62 & 0.64 & 0.062 & 0.058 & 0.114 & & & \\
\hline \multirow[t]{2}{*}{ Lingga } & Mean & 13 & 6.43 & 3.33 & 5.86 & 0.637 & 0.648 & 0.014 & 0.054 & 0.961 & 0.109 \\
\hline & SE & & 1.04 & 0.52 & 0.91 & 0.055 & 0.057 & 0.025 & & & \\
\hline \multirow[t]{2}{*}{ Similajau } & Mean & 32 & 5.57 & 2.61 & 4.28 & 0.580 & 0.565 & 0.031 & 0.344 & 0.711 & 0.688 \\
\hline & SE & & 0.57 & 0.37 & 0.39 & 0.094 & 0.064 & 0.107 & & & \\
\hline \multirow[t]{2}{*}{ Lambir } & Mean & 28 & 7.43 & 3.10 & 5.24 & 0.551 & 0.542 & -0.041 & 0.0039 & 1.000 & 0.0078 \\
\hline & SE & & 1.46 & 0.67 & 0.87 & 0.109 & 0.110 & 0.050 & & & \\
\hline \multirow[t]{2}{*}{ Limbang } & Mean & 27 & 7.86 & 3.47 & 5.58 & 0.519 & 0.566 & 0.149 & 0.027 & 0.981 & 0.055 \\
\hline & SE & & 1.57 & 0.956 & 0.96 & 0.102 & 0.100 & 0.090 & & & \\
\hline \multirow[t]{2}{*}{ Total } & Mean & 27.1 & 6.54 & 3.223 & $7.11 * *$ & 0.572 & 0.607 & 0.061 & - & - & - \\
\hline & SE & 1.41 & 0.42 & 0.22 & 0.76 & 0.029 & 0.026 & 0.032 & & & \\
\hline \multicolumn{9}{|c|}{ D. beccarii } & \multicolumn{3}{|c|}{ Wilcoxon test ${ }^{\neq}$} \\
\hline Population & & $N$ & $N_{\mathrm{a}}$ & $N_{\mathrm{e}}$ & $A_{\mathrm{r}}$ & $\mathrm{H}_{\mathrm{o}}$ & $H_{\mathrm{e}}$ & $F$ & $\mathbf{a}$ & b & c \\
\hline \multirow[t]{2}{*}{ Gunung Gading } & Mean & 28 & 2.57 & 1.57 & 2.13 & 0.301 & 0.273 & -0.006 & 0.594 & 0.500 & 1.000 \\
\hline & $\mathrm{SE}^{\dagger}$ & & 0.53 & 0.24 & 0.37 & 0.141 & 0.097 & 0.205 & & & \\
\hline \multirow[t]{2}{*}{ Kubah } & Mean & 15 & 2.71 & 1.74 & 2.46 & 0.381 & 0.357 & -0.048 & 0.578 & 0.500 & 1.000 \\
\hline & SE & & 0.36 & 0.25 & 0.29 & 0.114 & 0.086 & 0.155 & & & \\
\hline \multirow[t]{2}{*}{ Kubah } & Mean & 15 & 2.71 & 1.74 & 2.46 & 0.381 & 0.357 & -0.048 & 0.578 & 0.500 & 1.000 \\
\hline & SE & & 0.36 & 0.25 & 0.29 & 0.114 & 0.086 & 0.155 & & & \\
\hline \multirow[t]{2}{*}{ Bako } & Mean & 28 & 3.43 & 1.68 & 2.83 & 0.265 & 0.301 & 0.120 & 0.016 & 0.992 & 0.031 \\
\hline & SE & & 0.78 & 0.30 & 0.54 & 0.099 & 0.100 & 0.115 & & & \\
\hline \multirow[t]{2}{*}{ Batang Ai } & Mean & 35 & 3.71 & 1.92 & 2.70 & 0.441 & 0.365 & -0.168 & 0.281 & 0.781 & 0.562 \\
\hline & SE & & 0.78 & 0.38 & 0.48 & 0.133 & 0.105 & 0.059 & & & \\
\hline \multirow[t]{2}{*}{ Bukit Tangii } & Mean & 32 & 4.86 & 2.20 & 3.74 & 0.509 & 0.475 & -0.069 & 0.039 & 0.976 & 0.078 \\
\hline & SE & & 1.01 & 0.30 & 0.55 & 0.098 & 0.091 & 0.034 & & & \\
\hline \multirow[t]{2}{*}{ Mukah Hill } & Mean & 15 & 4.14 & 2.36 & 3.62 & 0.400 & 0.429 & 0.038 & 0.148 & 0.945 & 0.297 \\
\hline & SE & & 0.86 & 0.74 & 0.71 & 0.088 & 0.088 & 0.076 & & & \\
\hline Nyabau & Mean & 10 & 4.86 & 2.79 & 4.86 & 0.543 & 0.529 & -0.013 & 0.055 & 0.960 & 0.109 \\
\hline & SE & & 0.738 & 0.58 & 0.68 & 0.115 & 0.097 & 0.095 & & & \\
\hline Similajau & Mean & 13 & 5.14 & 3.56 & 4.94 & 0.648 & 0.644 & -0.027 & 0.766 & 0.289 & 0.578 \\
\hline & SE & & 0.91 & 0.82 & 0.77 & 0.065 & 0.065 & 0.068 & & & \\
\hline Sungai Asap & Mean & 10 & 2.71 & 1.98 & 2.71 & 0.329 & 0.356 & 0.025 & 0.578 & 0.500 & 1.000 \\
\hline & SE & & 0.61 & 0.52 & 0.56 & 0.084 & 0.099 & 0.079 & & & \\
\hline Deramakot & Mean & 14 & 2.86 & 1.60 & 2.62 & 0.245 & 0.311 & 0.160 & 0.055 & 0.961 & 0.109 \\
\hline & SE & & 0.40 & 0.23 & 0.32 & 0.078 & 0.080 & 0.121 & & & \\
\hline Total & Mean & 20.0 & 3.70 & 2.14 & $5.00 *$ & 0.406 & 0.404 & 0.004 & - & - & - \\
\hline & SE & 1.09 & 0.24 & 0.16 & 0.56 & 0.034 & 0.030 & 0.033 & & & \\
\hline
\end{tabular}

$N$ sample size, $N_{\mathrm{a}}$ actual number of alleles, $N_{\mathrm{e}}$ effective number of alleles, $A_{\mathrm{r}}$ allele richness calculated based on ten samples, $H_{\mathrm{o}}$ observed heterozygosity, $H_{\mathrm{e}}$ expected heterozygosity, $F$ inbreeding coefficient. ${ }^{\dagger}$ Standard error. ${ }^{\ddagger}$ The results of Wilcoxon tests for the BOTTLENECK analysis. Probabilities for testing (a) heterozygosity deficit, one-tailed test; (b) heterozygosity excess, one-tailed test; and (c) heterozygosity excess or deficit, two-tailed test.

Table 2 Summary of population genetics parameters estimated for $D$. aromatica and D. beccarii. 


\begin{tabular}{|c|c|c|c|}
\hline & $F_{I T}$ & $F_{S T}$ & $F_{I S}$ \\
\hline \multicolumn{4}{|c|}{ D. aromatica } \\
\hline Mean & $0.257 \pm 0.054$ & $0.189 \pm 0.021$ & $0.083 \pm 0.050$ \\
\hline $95 \% \mathrm{CI}$ & $(0.139-0.361)$ & $(0.150-0.227)$ & $(0.004-0.185)$ \\
\hline $99 \% \mathrm{CI}$ & $(0.151-0.392)$ & $(0.136-0.237)$ & $(-0.004-0.221)$ \\
\hline \multicolumn{4}{|c|}{ D. beccarii } \\
\hline Mean & $0.302 \pm 0.035$ & $0.308 \pm 0.046$ & $-0.070 \pm 0.052$ \\
\hline $95 \% \mathrm{CI}$ & $(0.247-0.383)$ & $(0.232-0.396)$ & $(-0.070-0.052)$ \\
\hline $99 \% \mathrm{CI}$ & $(0.231-0.413)$ & $(0.208-0.423)$ & $(-0.089-0.069)$ \\
\hline
\end{tabular}

F-statistics (Weir \& Cockerham, 1984) were calculated using FSTAT version 2.9.3.2. Standard errors of the means were calculated using the jackknife method. Confidence intervals (CIs) were calculated by the bootstrap method.

Table 3 Summary of $F$-statistics for $D$. aromatica and D. beccarii.

$\Delta K$ peak appeared at $K=2$ (Fig. 2a). The bar plot for $K=2$ is shown in Fig. 3a. Two clusters clearly differentiate the two species; however, these two clusters were mixed in the A7, B11, B12 and B16 populations (and to a lesser extent in A3 and B15). The B12 (D. beccarii) and A7 (D. aromatica) populations are sympatric in Similajau, Sarawak. In addition, $D$. aromatica has been recorded in the Deramakot area, where population B16 was sampled (Chua et al., 2010). Intensive hybridisation between these two species is suspected in these populations. The STRUCTURE analysis of the $D$. aromatica dataset alone revealed three peaks of $\Delta K$ at $K=2,4$ and 6 , but showed that the most likely number of genetic clusters was $K=2$ (Fig. 2b). The bar plot for D. aromatica at $K=2$ (Fig. 3b) showed that the populations were separated into two groups: Malay-Sumatra and Borneo. We noted, however, that the Bornean cluster was mixed to some extent with populations A5, in Peninsular Malaysia, and A6, on the Lingga Islands. At $K=4$, the Sumatran populations were separated from the Malay populations, and the central Sarawak population (A7) was separated from the eastern Sarawak populations (A8 and A9). At $K=6$, the populations in Sumatra and in Peninsular Malaysia were each further divided into two groups.

The STRUCTURE analysis of the $D$. beccarii dataset alone revealed two prominent peaks of $\Delta K$, at $K=3$ and 6 (Fig. 2c). At $K=3$ (Fig. 3c), the populations in Borneo were divided into three regional groups based on the dominant clusters: one in western Sarawak (B2, B3, B4, B5, B6 and B7), one in central to eastern Sarawak (B8, B9, B10, B13, B14 and B15) and one in central coastal Sarawak (B11 and B12) and Sabah (B16). Interestingly, the population in Peninsular Malaysia (B1) is a mixture of all three of these clusters. At $K=6$, the central Sarawak group was differentiated into two groups: B8 and the others (B9, B10, B13, B14 and B15). The central coastal Sarawak populations (B11 and B12) were differentiated from the Sabah population (B16), and the western Sarawak 
(a)

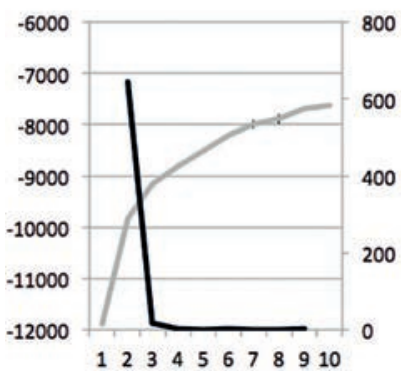

(b)

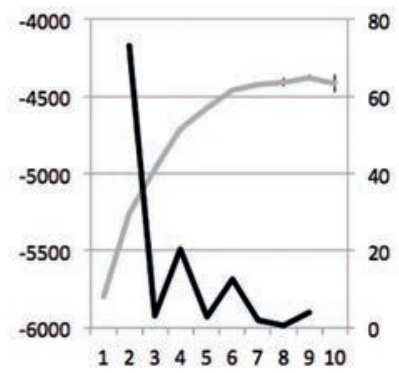

(c)

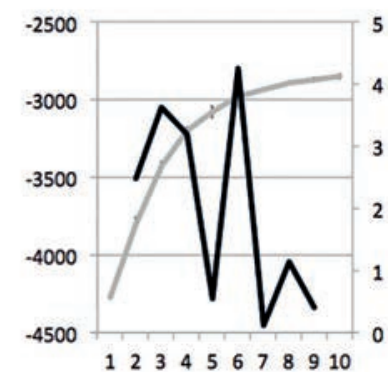

Fig. 2 Plots of the mean $\operatorname{LnP}(K)$ (grey lines) and the $\Delta K$ (black lines) obtained from the STRUCTURE analyses of (a) the combined $D$. aromatica and D. beccarii dataset, (b) D. aromatica and (c) D. beccarii. Standard deviations of the mean $\operatorname{LnP}(K)$ values are indicated with vertical bars.

(a)

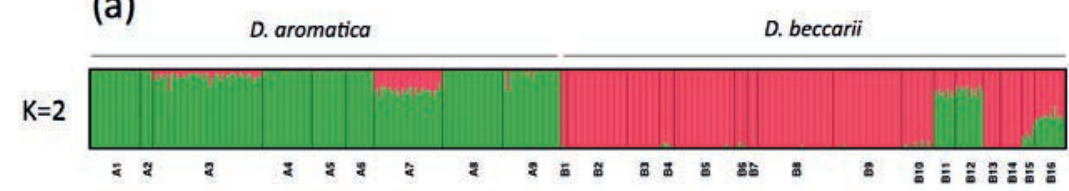

(b)

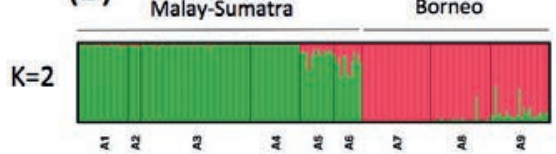

$K=4$

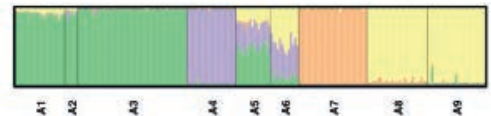

$\mathrm{K}=6$

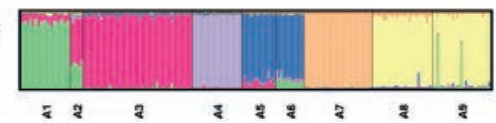

(c)

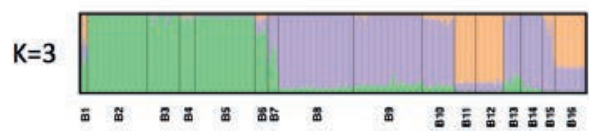

$K=6$

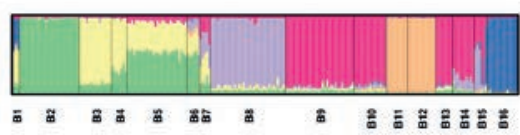

Fig. 3 Profile of membership coefficients for each individual (bar plot) of D. aromatica and D. beccarii, obtained from the STRUCTURE analysis. (a) Estimated genetic structure for $K=2$ for the combined dataset from nine populations of $D$. aromatica and 16 populations of $D$. beccarii. (b) Bar plots for the nine populations of $D$. aromatica for $K=2,4$ and 6 . (c) Bar plots for the 16 populations of $D$. aromatica for $K=3$ and 6.

populations were differentiated into two groups: B2 and the others (B3, B4, B5, B6 and B7), which were mixtures of two or three clusters.

In order to identify the boundaries or barriers where the genetic differentiation occurred and determine the strength of these barriers, we performed BARRIER analyses separately for $D$. aromatica and $D$. beccarii. Setting the number of barriers at four, the strongest barrier (100\% bootstrap probability) appeared between the Malay-Sumatra and Borneo groups in D. aromatica (Fig. 4a). There was a slightly weaker barrier 

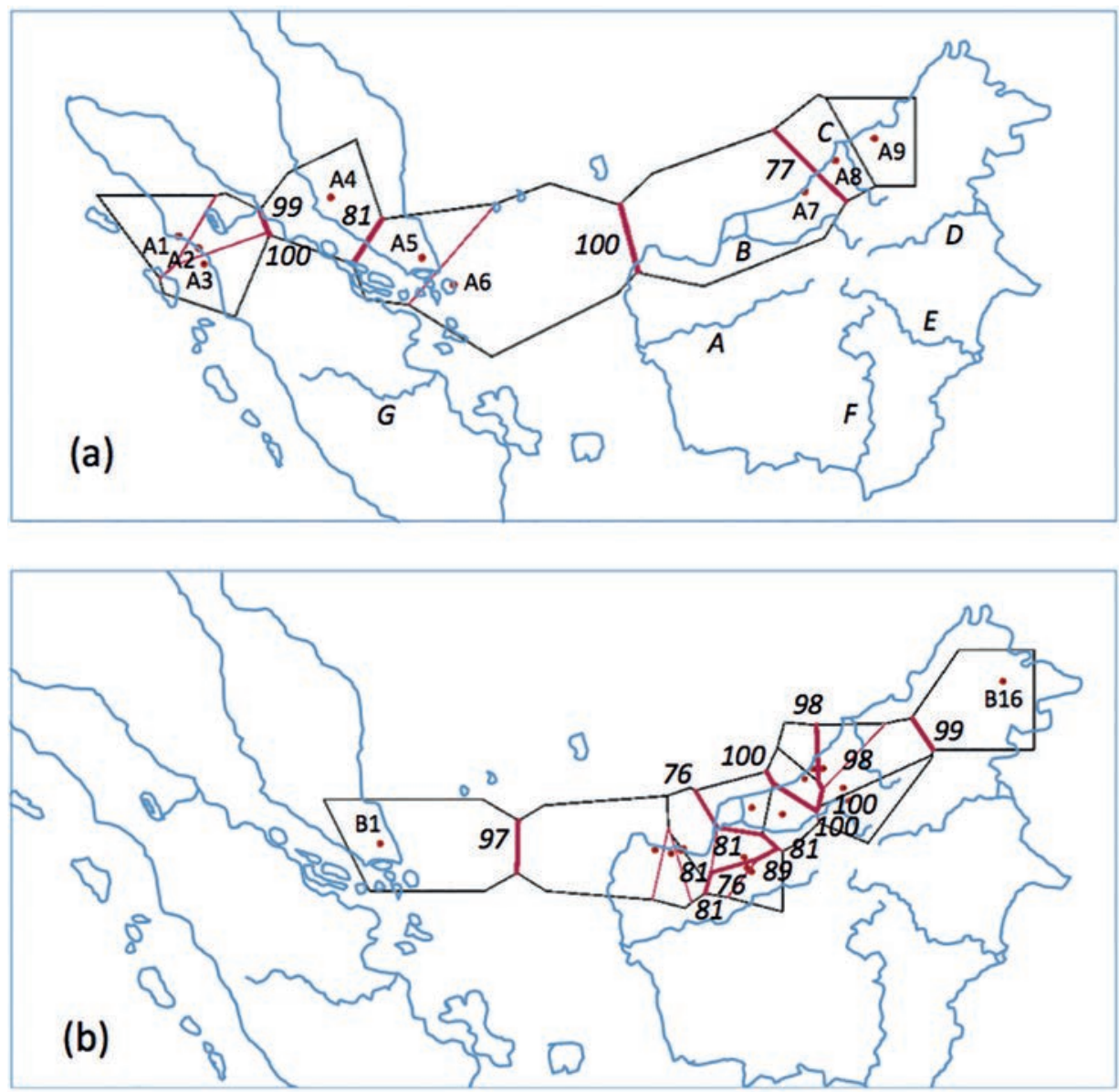

Fig. 4 Genetic barriers estimated by the BARRIER analysis, projected on a geographic map, for (a) $D$. aromatica and (b) D. beccarii. Red lines indicate barriers, with bootstrap probabilities (\%) next to them. The polygonal neighbourhood for each population is indicated by the Voronoï tessellation (black lines). In both figures solid red dots indicate sampling locations. The large rivers noted $A, B, C, D, E, F$ and $G$ are the Kapuas, Rajang, Baram, Kayan, Mahakam, Barito and Batang Hari Rivers, respectively. Population codes are omitted for D. beccarii, except for B1 and B16, but can be found in Fig. 1.

between Sumatra and Peninsular Malaysia (99-100\%). The other barriers occurred between A4 and A5 in Peninsular Malaysia (81\%) and between A7 and A8 in Borneo (77\%). We also set the number of barriers at four for D. beccarii (Fig. 4b). The strongest barriers (98-100\%) isolated the central coastal Sarawak group (B11 and B12) from the others. There were slightly weaker barriers between B1 and the others (97\%) and between B16 and the others (99\%). The western Sarawak group (B2, B3, B4 and B6) was also separated from the central Sarawak group (B7, B8, B9, B10, B13, B14 and B15) by the barriers crossing the area (76-89\%). 


\section{DISCUSSION}

The smaller $H_{\mathrm{e}}$ and larger $F_{\mathrm{ST}}$ obtained for $D$. beccarii suggest that the populations of this species are more intensively isolated, with more limited gene flow among them, than those of $D$. aromatica. The overall inbreeding coefficient, $F_{\text {IS }}$, was not significantly different from zero in either species, indicating that mating in both species is essentially random. The STRUCTURE analysis of the combined $D$. aromatica and $D$. beccarii dataset revealed one single prominent peak of $\Delta K$ at $K=2$ (Fig. 2a). For $K=2$, the two species were clearly separated into different clusters. This may indicate that the microsatellite markers we used are effective for discriminating between these two species. However, in several of the populations, considerable mixing of the two clusters was observed. The strong similarity of the bar plot pattern of B11 and B12, in coastal central Sarawak, to that of the sympatric A7 population of D. aromatica (Similajau) is confirmed by the similarly high proportions of the D. aromatica cluster observed in all three populations: $0.7593 \pm 0.0079$ (S.E.), $0.7110 \pm 0.0095$ and $0.7551 \pm 0.0099$ for A7, B11 and B12, respectively. However, the samples of the two species were collected at different times, and it is likely that we collected material from the same group of trees as different species. The mixing of the two clusters in these three populations raises the possibility that these trees are hybrids of $D$. aromatica and $D$. beccarii. The larger contribution of the $D$. aromatica cluster in these populations, together with the habitat in the lowland coastal area they inhabit, both favour D. aromatica and suggest that introgression is proceeding towards this species. Mixing of the two clusters was also observed in the A3, B15 and B16 populations, suggesting that hybridisation is occurring. Occasional hybridisation has also been reported among three closely related Shorea species - Shorea parvifolia Dyer, S. leprosula Miq. and S. curtisii Dyer ex King - in Peninsular Malaysia (Ishiyama et al., 2008) and in Singapore (Kamiya et al., 2011), and these species are in the same section, Mutica. A case of hybridisation was also observed in the genus Dryobalanops, between $D$. aromatica and $D$. lanceolata, in the sympatric habitat of Lambir Hills National Park. The putative hybrids grow in the middle of the habitats occupied by $D$. aromatica and D. lanceolata and showed intermediate leaf morphology (Itoh et al., unpublished data). Hybridisation may occur where two closely related species come into contact during range expansion (Rieseberg et al., 2007; Ishiyama et al., 2008). A recent study has shown that introgression is likely to take place preferentially from the resident species towards the invading species (Currat et al., 2008). This suggests that the hybridisation is the result of invasion by $D$. beccarii into $D$. aromatica territory in the central coastal Sarawak populations. However, population size change was not detected in any of the A7, B11 or B12 populations by the BOTTLENECK analysis (Table 2). The very low variation in the proportion of the clusters represented in these populations indicated by the STRUCTURE analysis suggests that the hybridisation was an old event, and populations are not under a wave of invasion. The lack of pure D. aromatica or D. beccarii individuals in these populations also supports this speculation. In another pair of sympatric populations in Gunung Panti 
(A5 and B1), the two species are clearly differentiated, and no signs of hybridisation were observed.

The STRUCTURE analysis of $D$. aromatica alone showed that the populations were divided into two groups: Malay-Sumatra and Borneo (Fig. 3b). A strong barrier separated them (Fig. 4a). The proposed "savanna corridor" (Heaney, 1991), a large belt of grassland thought to have existed in the middle of the dry Sunda Shelf, could be an environmental barrier that prevents gene flow. The mixing of the Sumatra and Borneo clusters in the Peninsular Malaysian populations (Fig. 3b) suggests a past admixture of the clusters and that the savanna corridor was open at some point, allowing some gene flow. The separation of Borneo from the eastern edge of the Sunda Shelf around 8,000 years ago by rising seawater (Voris, 2000) could finally have blocked all gene flow. The secondary barrier that was indicated in the Malacca Strait probably corresponds to the opening of that strait about 4,000 to 3,000 years ago (Voris, 2000). The formation of the clusters, however, can be traced back to the earlier similar changes in land area in the Pleistocene. Similar groupings were also observed in Shorea leprosula revealed by cpDNA sequence variations (Ohtani et al., 2013) and in S. parvifolia revealed by nuclear DNA sequence variations (Iwanaga et al., 2012). The estimated splitting time is 2.6 to 0.7 MYA and 0.28 to 0.09 MYA for S. leprosula (Ohtani et al., 2013) and $S$. parvifolia (Iwanaga et al., 2012), respectively, setting the time of clustering long before the last glacial period. Our result supports the idea that present tropical rain forests in the Sundaic region are in a refugial state after experiencing expansion and overlap in the last glacial age (Cannon et al., 2009; Raes et al., 2014).

The STRUCTURE and BARRIER analyses suggested that individuals of $D$. beccarii were separated into four geographically distinct groups in Borneo: western Sarawak, central inland Sarawak, central coastal Sarawak and Sabah. There were strong barriers between Peninsular Malaysia and Borneo, and between Sabah and Sarawak. Another barrier separated the central coastal from the central inland Sarawak populations. A deep genetic split between Sabah and Sarawak has been observed in other species, such as the legume genus Spatholobus Hassk. (Ridder-Numan, 1998), the stone oak Lithocarpus Blume (Cannon \& Manos, 2003) and Macaranga Thouars species (Bänfer et al., 2006), as well as in fauna such as orang-utans (Warren et al., 2001), rodents (Gorong et al., 2004) and some birds, for example forktails (Moyle et al., 2005). Because of the limited distance of gene flow both via insect-mediated pollen dispersal and gravity or gyration dispersal of seeds (Harata et al., 2011; Kettle et al., 2011; de Morais et al., 2015), high mountain ridges and large rivers could be considered as effective barriers. The Crocker range, lying between B16 and the others, has probably acted as a barrier. Although the genetic structure in Sarawak is not as pronounced as the differentiation between the populations in Sabah and Sarawak, there is nevertheless some differentiation. Several large rivers in Sarawak, such as the Rajang River in the centre of the region, restrict distribution ranges and may have functioned as barriers against gene flow.

The clustering suggested by the STRUCTURE analysis is especially interesting in that the isolated population of $D$. beccarii in Peninsular Malaysia (B1) was a mixture of 
the four Bornean clusters. Peninsular Malaysia is separated from Borneo by a distance of about $500 \mathrm{~km}$. Over such a distance gene flow is unlikely; it is more plausible that the mixture occurred when $D$. beccarii expanded into Peninsular Malaysia during the last glacial period. We therefore suggest that $\mathrm{B} 1$ is a relic of the most recent range expansion of $D$. beccarii, during the last glacial period.

In this study we have found that historical events, most importantly those occurring after the last glacial period, have imprinted their effects deeply on the genetic structure of tropical rain forest trees. The differential pattern in genetic variation and genetic structure of these two closely related Dryobalanops species suggests that they may have been influenced mainly by two factors. One is the longer span of historical change traced back to the speciation of the genus Dryobalanops in the Pliocene. Today the distribution of Dryobalanops species is somewhat scattered and restricted, and absent altogether from Java; however, abundant fossils of Dryobalanops have been recorded in a broad range of Sundaland including Java and even extending to Burma (Slooten, 1932; Mandang \& Kagemori, 2004). The current species distribution is therefore often considered as remnants, which in former times expanded in a much larger area (Slooten, 1932). The second is the difference caused by species-specific intrinsic factors such as pollen and seed dispersal abilities, light acquisition capacity, nutrient utilisation capacity and drought tolerance. Comparative studies of the fine genetic structure of these two species may be needed for further understanding of the generation of the large-scale genetic structure in Dryobalanops.

\section{ACKNOWLEDGEMENTS}

The authors thank Mohamad A. Latiff (UKM, Malaysia), Joseph J. Kendawang (Sarawak Forestry Cooperation, Sarawak, Malaysia), and Eyen Khoo and John B. Sugau (both of the Forest Research Centre, Forestry Department of Sabah, Malaysia) for their kind help with sample collection. This study was supported by the Environment Research and Technology Development Fund (D-0901) from the Ministry of the Environment, Japan, and also by a Grant-in-Aid from the Japan Society for Promotion of Science (No. 26304017) to Ko Harada.

\section{REFERENCES}

ANTAO, T., LOPES, A., LOPES, R., BEJA-PEREIRA, A. \& LUIKART, G. (2008). LOSITAN: a workbench to detect molecular adaptation based on a FT-outlier method. BMC Bioinforma, 9: 323.

APPANAH, S. \& TURNBULL, J.M. (1998). A Review of Dipterocarps: Taxonomy, Ecology and Silviculture. Center for International Forestry Research, Bogor.

ASHTON, P.S. (1982). Dipterocarpaceae. In: VAN STEENIS, C.G.G.J. (ed.). Flora Malesiana, ser. 1, Spermat. 9, pt. 2. Martinus Nijhoff, The Hague, pp. 237-552. 
BÄNFER, G., MOOG, U., FIALA, B., MOHAMED, M., WESING, K. \& BLATTNER, F.R. (2006). A chloroplast genealogy of myrmecophytic Macaranga species (Euphorbiaceae) in Southeast Asia reveals hybridisation, vicariance and long distance dispersals. Molecular Ecology, 15: 4409-4424.

BEAUMONT, M.A. \& NICHOLS, R.A. (1996). Evaluating loci for use in the genetic analysis of population structure. Proceedings of the Royal Society B, 263: 1619-1626.

CANNON, C.H. \& MANOS, P.S. (2003). Phylogeography of the Southeast Asian stone oaks (Lithocarpus). Journal of Biogeography, 30: 211-226.

CANNON, C.H., MORLEY, R.J. \& BUSH, A.B.G. (2009). The current refugial rainforests of Sundaland are unrepresentative of their biogeographic past and highly vulnerable to disturbance. Proceedings of the National Academy of Sciences U.S.A., 106: 11188-11193.

CHUA, L.S.L., SHHAIDA, M., HAMIDAH, M. \& SAW, L.G. (2010). Malaysia Plant Red List, Peninsular Malaysian Dipterocarpaceae. Research Pamphlet No. 129. Forest Research Institute Malaysia, Kepong.

COMES, H.P. \& KADEREIT, J.W. (1998). The effect of Quaternary climate changes on plant distribution and evolution. Trends in Plant Science, 3: 432-438.

CONSERVATION INTERNATIONAL (2010). Available online: https://www.conservation.org/ (accessed 1 February 2018).

CORLETT, R.T. (2014). The Ecology of Tropical East Asia (2nd edn). Oxford University Press, Oxford.

CORNUET, J.M. \& LUIKART, G. (1998). Description and power analysis of two tests for detecting population bottlenecks from allele frequencies. Genetics, 144: 2001-2014.

CURRAT, M., RUEDI, M., PETIT, R.J.J. \& EXCOFFIER, L. (2008). The hidden side of invasions: massive introgression by local genes. Evolution, 62: 1908-1920.

DE MORAIS, C.T. \& 11 others (2015). Understanding local patterns of genetic diversity in dipterocarps using a multi-site, multi-species approach: Implications for forest management and restoration. Forest Ecology and Management, 356: 153-165.

DIERINGER, D. \& SCHLÖTTERER, C. (2003). MICROSATELLITE ANALYSER (MSA): a platform independent analysis tool for large microsatellite data sets. Molecular Ecology Resources, 3: 167-169.

DOYLE, J.J. \& DOYLE, J.L. (1990). Isolation of plant DNA from fresh tissue. Focus, 12: 13-15.

DWIYANTI, F.G., CHONG, L., DIWAY, B., LEE, Y.F., SIREGAR, I.Z., ATOK, S., KAMIYA, K., NINOMIYA, I. \& HARADA, K. (2015). Population genetic diversity in the genus Dryobalanops Gaertn. f. (Dipterocarpaceae) based on nuclear microsatellite markers. J-SustaiN, 3: 12-20.

EARL, D.A. \& VON HOLDT, B.M. (2012). STRUCTURE HARVESTER: a website and program for visualizing STRUCTURE output and implementing the Evanno method. Conservation Genetics Resources, 4: 359-361.

EVANNO, G., REGNAUT, S. \& GOUDET, J. (2005). Detecting the number of clusters of individuals using the software STRUCTURE: a simulation study. Molecular Ecology, 14: 2611-2620.

FAO (2010). Global Forest Resources Assessment 2010. United Nations Food and Agriculture 
Organization, Rome. Available online: www.fao.org/forestry/fra/fra2010/en (accessed 3 September 2017).

FINGER, A., KETTLE, C.J., KAISER-BUNBURY, C.N., VALENTIN, T., MOUGAL, J. \& GHAZOUL, J. (2012). Forest fragmentation genetics in a formerly widespread island endemic tree: Vateriopsis seychellarum (Dipterocarpaceae). Molecular Evolution, 21: 2369-2382.

FUKUE, Y., KADO, T., LEE, S.-L., NG, K.K.S., MUHAMMAD, N. \& TSUMURA, Y. (2007). Effects of flowering tree density on the mating system and gene flow in Shorea leprosula (Dipterocarpaceae) in Peninsular Malaysia. Journal of Plant Research, 120: 413-420.

GHAZOUL, J. \& SHEIL, D. (2010). Tropical Rain Forest Ecology, Diversity, and Conservation. Oxford University Press, Oxford.

GORONG, A.J., SINAGA, M.H. \& ENGSTROM, M.D. (2004). Vicariance or dispersal? Historical biogeography of three Sunda shelf murine rodents (Maxomys surifer, Leopoldamys sabanus and Maxomys whiteheadi). Biological Journal of the Linnean Society, 81: 91-109.

GOUDET, J. (2001). FSTAT (version 2.9.3.2). Available online: www2.unil.ch/popgen/softwares/ fstat.htm (accessed 30 September 2016).

HAMRICK, J.L., GODT, M.J.W. \& SHERMAN-BROYLES, S.L. (1992). Factors influencing levels of genetic diversity in woody plant species. New Forests, 6: 95-124.

HANSEN, M.C., STEHMAN, S.V. \& POTAPOV, P.V. (2010). Quantification of global gross forest cover loss. Proceedings of the National Academy of Sciences of the USA, 107: 8650-8655.

HARATA, T., NANAMI, S., YAMAKURA, T., MATSUYAMA, S., DIWAY, B.M., TAN, S. \& ITOH, A. (2011). Fine-scale spatial genetic structure of ten Dipterocarp tree species in a Bornean rain forests. Biotropica. doi: 10.1111/j.1744-1729.2011.00836.x

HEANEY, L.R. (1991). A synopsis of climatic and vegetational change in Southeast Asia. Climate Change, 19: 53-61.

HEUERTZ, M., HUSMAN, J.-F., JARDY, O.J., VENDRAMIN, G.G., FRASCARIA-LACOSTE, N. \& VEKEMANS, X. (2004). Nuclear microsatellites reveal contrasting patterns of genetic structure between western and southeastern European populations of the common ash (Fraxinus excelsior L.). Evolution, 58: 976-988.

HEWITT, G.M. (2000). The genetic legacy of the Quaternary ice ages. Nature, 405: 907-913.

ISHIYAMA, H., INOMATA, N., YAMAZAKI, T., SHUKOR, N.A.A. \& SZMIDT, A.E. (2008). Demographic history and interspecific hybridization of four Shorea species (Dipterocarpaceae) from Peninsula Malaysia inferred from nucleotide polymorphism in nuclear gene regions. Canadian Journal of Forest Research, 38: 996-1007.

ISMAIL, S.A., GHAZOUL, J., RAVIKANTH, G., UMA SHAANKER, R., KUSHALAPPA, C.G. \& KETTLE, C.J. (2012). Does long-distance pollen dispersal preclude inbreeding in tropical trees? Fragmentation genetics of Dysoxylum malabaricum in an agro-forest landscape. Molecular Ecology, 21: 5484-5496.

IUCN (2017).The IUCN Red List of Threatened Species. Version 2017-1. Available online: www. iucnredlist.org (accessed 12 May 2017).

IWANAGA, H., TESHIMA, K.M., KHTAB, I.A., INOMATA, N., FINKELDEY, R., SIREGAR, I.Z., SIREGAR, U.J. \& SZMIDT, A.E. (2012). Population structure and demographic 
history of a tropical lowland rainforest tree species Shorea parvifolia (Dipterocarpaceae) from Southeastern Asia. Ecology and Evolution, 2: 1663-1675.

JAKOBSSON, M. \& ROSENBERG, N.A. (2007). CLUMPP: a cluster matching and permutation program for dealing with label switching and multimodality in analysis of population structure. Bioinformatics, 23: 1801-1806.

KAMIYA, K., GAN, Y.Y., SHAWN, K., LUM, Y., KHOO, M.S., CHUA, S.C. \& FAIZU, N.N.K. (2011). Morphological and molecular evidence of natural hybridization in Shorea (Dipterocarpaceae). Tree Genetics \& Genomes, 7: 293-306.

KAMIYA, K. \& 10 others (2012). Demographic history of Shorea curtisii (Dipterocarpaceae) inferred from chloroplast DNA sequence variations. Biotropica, 44: 577-585.

KETTLE, C.J., HOLLINGSWORTH, P.M., BURSLEM, D.F.R.P., MAYCOCK, C.R., KHOO, E. \& GHAZOUL, J. (2011). Determinants of fine-scale spatial genetic structure in three cooccurring rain forest canopy trees in Borneo. Perspectives in Plant Ecology, Evolution and Systematics, 13: 45-54.

KETTLE, C.J., MAYCOCK, C.R. \& BURSLEM, D. (2012). New directions in Dipterocarp biology and conservation: A synthesis. Biotropica, 44: 658-660.

LANGNER, A., MIETTINEN, J. \& SIEGERT, F. (2007). Land cover change 2002-2005 in Borneo and the role of fire derived from MODIS imagery. Global Change Biology, 13: 2329-2340.

LEE, S.L., TANI, N., NG, K.K.S. \& TSUMURA, Y. (2004). Isolation and characterization of 20 microsatellite loci for an important tropical tree Shorea leprosula (Dipterocarpaceae) and their applicability to S. parvifolia. Molecular Ecology Notes, 4: 222-225.

LI, W.-H. (1997). Molecular Evolution. Sinauer Associates, Massachusetts, USA.

LUIKART, G., ALLENDORF, F.W., CORNUET, J.-M. \& SHERWIN, W.B. (1998). Distortion of allele frequency distribution provides a test for recent population bottleneck. Journal of Heredity, 89: 238-247.

MANDANG, Y.I. \& KAGEMORI, N. (2004). A fossil wood of Dipterocarpaceae from Pliocene deposit in the west region of Java Island, Indonesia. Bioderversitas, 5: 28-35.

MANEL, S., SCHWARTZ, M.K., LUIKART, G. \& TABERLET, P. (2003). Landscape genetics: combining landscape ecology and population genetics. Trends in Ecology and Evolution, 18: 189-197.

MANNI, F., GUERARD, E. \& HEYER, E. (2004). Geographic patterns of (genetic, morphologic, linguistic) variation: how barriers can be detected by 'Monmonier's algorithm'. Human Biology, 76: 173-190.

MIETTINEN, J.K., SHI, C.-H. \& LIEW, S.-C. (2011). Deforestation rates in insular Southeast Asia between 2000 and 2010. Global Change Biology, 17: 2261-2270.

MONMONIER, M. (1973). Maximum-difference barriers; an alternative numerical regionalization method. Geographical Analysis, 3: 245-261.

MOYLE, R.G., SCHILTHUIZEN, M., RAHMAN, M.A. \& SHELDON, F.H. (2005). Molecular phylogenetic analysis of the white-crowned forktail Enicurus leschenaulti in Borneo. Journal of Avian Biology, 36: 96-101.

MYERS, N., MITTERMEIER, R.A., DA FONSECA, G.A.B. \& KENT, J. (2000). Biodiversity hotspots for conservation priorities. Nature, 403: 853-858. 
NAITO, Y., KANZAKI, M., IWATA, H., OBAYASHI, K., LEE, S.-L., MUHAMMAD, N., OKUDA, T. \& TSUMURA, Y. (2008). Density-dependent selfing and its effects on seed performance in a tropical canopy tree species, Shorea acuminata (Dipterocarpaceae). Forest Ecology and Management, 256: 375-383.

NAITO, Y., KONUMA, A., IWATA, H., SUYAMA, Y., SEIWA, K., OKUDA, T., LEE, S.-L., MUHAMMAD, N. \& TSUMURA, Y. (2005). Selfing and inbreeding depression in seeds and seedlings of Neobalanocarpus heimii (Dipterocarpaceae). Journal of Plant Research, 118: 423-430.

NANAMI, S., IKEDA, S., TANI, N., TAN, S., DIWAY, B., HARADA, K., TSUMURA, Y., ITOH, A. \& YAMAKURA, T. (2007). Development of microsatellite markers for Dryobalanops aromatica (Dipterocarpaceae), a tropical emergent tree in Southeast Asia. Molecular Ecology Notes, 7: 623-625.

NEI, M. (1978). Estimation of average heterozygosity and genetic distance from a number of individuals. Genetics, 89: 538-590.

NEWMAN, M.F., BURGESS, P.F. \& WHITMORE, T.C. (1998). Foresters' Manual of Dipterocarps: Borneo Island, medium and heavy hard woods. Royal Botanic Garden Edinburgh/Center for International Forestry Research, Jakarta.

OBAYASHI, K., TSUMURA, Y., IHARA-UJINO, T., NIIYAMA, K., TANOUCHI, H., SUYAMA, Y., WASHITANI, I., LEE, C.-T., LEE, S.-L. \& MUHAMMAD, N. (2002). Genetic diversity and outcrossing rate between undisturbed and selectively logged forest of Shorea curtisii (Dipterocarpaceae) using microsatellite. International Journal of Plant Sciences, 163: 151-158.

OHTANI, M. \& 15 others (2013). Nuclear chloroplast DNA phylogeography reveals Pleistocene divergence and subsequent secondary contact of two genetic lineages of the tropical rainforest tree species Shorea leprosula (Dipterocarpaceae) in South-East Asia. Molecular Ecology, 22: 2264-2279.

OOSTERHOUT, C.V., HUTCHINSON, W.F., WILLS, D.P.M. \& SHIPLEY, P. (2004). MICROCHECKER: software for identifying and correcting genotyping errors in microsatellite data. Molecular Ecology Notes, 4: 535-538.

PEAKALL, R. \& SMOUSE, P.E. (2006). GENALEX 6: genetic analysis in Excel. Population genetic software for teaching and research. Molecular Ecology Notes, 6: 288-295.

PRITCHARD, J.K., STEPHEN, M. \& DONNELLY, P. (2000). Inference of population structure using multilocus genotype data. Genetics, 155: 945-959.

RAES, N., CANNON, C.H., HIJMANS, R.J., PIESSENS, T., SAW, L.G., VAN WELZEN, P.C. \& SLIK, J.W.F. (2014). Historical distribution of Sundaland's dipterocarp rainforests at Quaternary glacial Maxima. Proceedings of the National Academy of Sciences of the USA, 111: $16790-16795$.

RIDDER-NUMAN, J.W.A. (1998). Historical biogeography of Spatholobus (LeguminosaePapilionoideae) and allies in SE Asia. In: HALL, R. \& HOLLOWAY, J.D. (eds)

Biogeography and Geological Evolution of SE Asia. Backhuys Publishers, Leiden, pp. 259-277.

RIESEBERG, L.H., KIM, S.C., RANDELL, R.A., WHITNEY, K.D., GROSS, B.L., LEXER, C. \& CLAY, K. (2007). Hybridization and the colonization of novel habitats by annual sunflowers. Genetica, 129: 149-165. 
ROSENBERG, N.A. (2004). DISTRUCT: a program for the graphical display of population structure. Molecular Ecology Notes, 4: 137-138.

SLOOTEN, D.F. VAN (1932). The Dipterocarpaceae of the Dutch East Indies. VI. The genus Dryobalanops. Bulletin du Jardin botanique de Buitenzorg, série III, 3: 1-45.

SODHI, N.K., KOH, L.P., BROOKS, B.W. \& NG, P.K.L. (2004). Southeast Asian biodiversity: an impending disaster. Trends in Ecology and Evolution, 19: 654-660.

SYMINGTON, C.F. (2004). Foresters' Manual of Dipterocarps (2nd edn, rev. ASHTON, P.S. \& APPANAH, S.). Malayan Forest Records, No. 16. Forest Research Institute Malaysia and Malaysian Nature Society, Kuala Lumpur.

TAKEUCHI, Y., ICHIKAWA, S., KONUMA, A., TOMARU, N., NIIYAMA, K., LEE, S.-L., MUHAMMAD, N. \& TSUMURA, Y. (2004). Comparison of the fine-scale genetic structure of three dipterocarp species. Heredity, 92: 323-328.

TÜXEN, R. (1956). Die heutige potentielle natürliche Vegetation als Gegenstand der Vegetatonskartierung. Angew. Pflanzensoziol., 13: 5-42.

VORIS, H.K. (2000). Maps of Pleistocene sea levels in Southeast Asia: shorelines, river systems and time durations. Journal of Biogeography, 27: 1153-1167.

WARREN, K.S., VERSCHOOR, E., LANGENHUIZEN, S., HERIYANTO, SWAN, R.A., VIGILANT, L. \& HEENEY, J.L. (2001) Speciation and intrasubspecific variation of Bornean orangutans, Pongo pygmaeus pygmaeus. Molecular Biology and Evolution, 18: 472-480.

WEIR, B.S. \& COCKERHAM, C.C. (1984). Estimating F-statistics for the analysis of population structure. Evolution, 38: 1358-1370. 